\title{
EFFECT OF USING POTATO TOPS HAY IN GROWING RABBIT DIETS ON GROWTH PERFORMANCE, DIGESTIBILITY AND CARCASS TRAITS
}

\author{
T.H. Tag El-Din ${ }^{1}$, A. A. El-Serwy ${ }^{1}$ and A. L. Awad $^{2}$ \\ 1- Department of Poultry Production, Faculty of Agriculture, Mansoura University. \\ 2-Animal Production Research Institute, Agriculture Research Center
}

\section{SUMMARY}

The present study was carried out to investigate the effect of using potato tops hay instead of clover hay at levels of 0, 5, 10, 15, 20 and $30 \%$ in rabbit diets on the growth performance, feed efficiency, digestibility coefficient and some carcass traits of the NZW rabbits during the growing period from 5 to 13 weeks of age.A total of sixty NZW rabbits at 5 weeks of age were randomly divided into 6 groups, each of 10 individuals, the average body weight of rabbits in the experimental groups at beginning of the experiment ranged from 715 to $718 \mathrm{~g}$. Each treatment group received one of six experimental pelleted diets. At 11 weeks of age, digestibility trial was carried out for five days and, at 13 weeks of age, five individuals were slaughtered to study carcass and offal traits.

Results obtained indicated that, live body weight, daily weight gain, daily feed intake and production index of rabbits were not affected significantly, while, feed conversion, protein efficiency ratio and efficiency of energy utilization of rabbits were affected significantly $(p<0.01)$ by feeding different levels of dried potato tops in diets through the experiment from 5 to 13 weeks of age. Rabbits fed on 20\% DPT consumed less feed intake and recorded better value of feed conversion and protein efficiency ratio than other groups during the whole experimental period from 5 to 13 weeks of age. Rabbits fed diets containing 5,10,15 and 20\% DPT had better values of feed conversion, protein efficiency ratio and efficiency of energy utilization than the control group, while, the group fed diet contains 30\% DPT had recorded lower values at the whole period from 5-13 weeks of age.

Carcass traits were not affected significantly among treatments, while, digestibility coefficient and nutritive value were affected significantly due to feeding dried potato tops hay in rabbit diets. The highest values of digestibility coefficients of all nutrients except (EE) were recorded for rabbits fed 5 and 10\% DPT in the diet. However, nutritive values were better for all groups fed DPT than the control group. The obtained results from this experiment indicate that potato tops hay can be used instead of clover hay up to 30\% of the diet without any detrimental effect, while should not exceed to $10 \%$ from the practical point of view.

Keywords: Rabbits, growth performance, digestibility, carcass traits and potato tops hay 


\section{INTRODUCTION}

Feeding cost represents the greatest part (about 65 to $70 \%$ ) of the total cost of animal production. Therefore, any effort of reducing the feeding cost will increase the net profit of the producers. Recently, many studies investigated the introducing of some agricultural by-products in complete pelleted feeds of rabbits instead of clover hay which represents about $30-40 \%$ of the diet. In Egypt, there is a need to seek for more untraditional animal feed resources to compensate the shortage of the available amount of animal feeds, especially fooders and hays, to cover the requirements of the stocks. Potato is the most important vegetable crop in Egypt, at harvesting time, a huge amount of green tops of potato are not used by farmers and they neglect them without any useful use. Vegetable production results in a considerable quantity of by-products, some of which are unattractive to people and some of which are unpalatable or poorly utilized when eaten by people. Animals have a substantial role in making use of such by-products, and, indeed the economics of production systems increasingly depend up on efficient use of all the component resources (Spedding, 1979). Here, such animals as rabbits, because of their high reproductive rates, are very efficient converters of fibrous vegetable wastes into lean meat. These animals are also flexible in terms of their low capital investment (Walsingham, 1972) and their ability to cape with seasonally of vegetable production because of their short breeding season (Cheeke, 1977). This is a very important consideration for small holders in developing countries.In the field of using agricultural processing by-products, many attempts were recently made to utilize some of these by-products in rabbit feeding such as artichoke (Zeweil, 1992 a and ElSayaad et al., 1995) and tomato pomace (Ahmed et al., 1994 and Abd El-Razik, 1996). Other materials were also studied like carrot tops hay (El-Kerdawy et al., 1992), cassava foliage (El-Gendy, 1994), desert forages (Abdel-Samee et al., 1992 \& 1994), sweet potato (Soliman, 1995), acacia and water hyacinth (Eleraky and Mohamed, 1996), okra and sugar beet by-products (Tag-El-Din, 1996) and turnips (El-Meligy, 1996). However, no attempts were made on using potato tops in complete pelleted rabbit diets in Egypt. Therefore, the present study was carried out to investigate the effect of substitution of clover hay by dried potato tops in complete pelleted growing rabbits diets at varying levels on some productive traits in order to get some knowledge on the possibility of feeding rabbits on potato tops and to what extent we can replace it instead of clover hay.

\section{MATERIALS AND METHODS}

This study was carried out at the rabbitry of Agricultural Experimental and Research Center, Faculty of Agriculture, Mansoura University within the project "Production Improvement of Rabbits by crossbreeding and using untraditional diets in Dakahlia Governorate" which belonged to Mansoura University during the period from February to April 1996.

\section{The experimental design :}

The work was carried out to study the effect of using potato tops hay instead of clover hay at levels of $0,5,10,15,20$ and $30 \%$ in rabbit diets on the growth performance, feed efficiency, digestibility coefficient and some carcass traits of the 
NZW rabbits during the growing period from 5 to 13 weeks of age. The experimental design is summarized in Table (1).

Table 1. Design of the experiment

\begin{tabular}{ccc}
\hline Treatment & Potato tops hay $\%$ & Clover hay $\%$ \\
\hline 1 & 0.0 & 30.0 \\
2 & 5.0 & 25.0 \\
3 & 10.0 & 20.0 \\
4 & 15.0 & 15.0 \\
5 & 20.0 & 10.0 \\
6 & 30.0 & 0.0 \\
\hline
\end{tabular}

Table 2. The chemical composition of Potato tops hay and Clover hay

\begin{tabular}{ccc}
\hline Traits \% & Potato tops hay \% & Clover hay \% \\
\hline Dry matter & 88.88 & 90.00 \\
Crude fiber & 13.53 & 20.70 \\
Crude protein & 11.74 & 17.00 \\
Ether extract & 2.46 & 2.70 \\
N.F.E & 40.38 & 39.60 \\
Ash & 20.77 & 10.00 \\
\hline
\end{tabular}

\section{Experimental animals:}

A total of sixty NZW rabbits at 5 weeks of age were randomly divided into 6 groups, each of 10 individuals. The average body weight of rabbits in the experimental groups at the beginning of the experiment groups ranged from 715 to $718 \mathrm{~g}$. Each treatment group received one of six experimental pelleted diets.

\section{Experimental diets:}

Six experimental diets were formulated from the available and prevailing ingredients for feeding rabbits. Fresh potato tops were cut during crop harvesting at April (1995), then they were sun dried carefully, mashed and then stored. The diets were manufactured at November (1995) and contained dried potato tops hay instead of clover hay at levels of $0,5,10,15,20$ and $30 \%$ potato tops hay, the composition and chemical analysis of the experimental diets are presented in Table (3).

\section{Management:}

Young rabbits were housed individually in galvanized cages in well-ventilated pens. Each cage have a stainless steel nipple for drinking and a feeder allowing to record feed intake for each rabbit. Feed and water offered ad-libitum. All rabbits in the treatment group were kept under the same managerial, hygienic and environmental conditions during the experimental period.

\section{Digestibility trials:}

At 11 weeks of age, six digestibility trials were carried out to determine the digestibility coefficient of the different nutrients and feeding values of the experimental diets. Four NZW rabbits from each treatment group were used in each trial. A preliminary period of 7 days were followed by 5 days as collection period for faeces. The feed intake was accurately determined and coprophagy was not 
prevented. Quantitative collection of faeces started 24 hours after offering the daily feed, using aluminum dishes $(20 \times 10 \times 3.5 \mathrm{~cm})$. The faeces of each rabbit were collected every day in the morning. Any shaded gar or foreign materials were discarded, then the faeces were dried at $60^{\circ} \mathrm{C}$ for 8 hour's a forced draught oven, then bulked. At the end of the collection period, all collected faeces for each rabbit were mixed, ground and stored for chemical analysis.

\section{Slaughter test:}

At 13 weeks of age, five rabbits from each treatment group were randomly chosen for slaughter test. Rabbits were fasted for 18 hours before slaughtering, then were weighed individually as preslaughter weight. Rabbits were slaughtered by cutting the jugular veins. After complete bleeding, they were weighed, skinned and then eviscerated. Fur, empty carcass, head and liver were immediately weighed. The blood loss was calculated by difference between weights before and after slaughtering. Dressed weight (total edible parts) were calculated as the total weight of carcass plus head and liver. All traits were calculated as percentage of the pre-slaughter weight.

Table 3. Composition and analysis of the experimental pelleted diets

\begin{tabular}{|c|c|c|c|c|c|c|}
\hline Ingredients & Control & $\begin{array}{l}\text { 5\% } \\
\text { D.P.T }\end{array}$ & $\begin{array}{l}\text { 10\% } \\
\text { D.P.T }\end{array}$ & $\begin{array}{l}15 \% \\
\text { D.P.T }\end{array}$ & $\begin{array}{l}20 \% \\
\text { D.P.T }\end{array}$ & $\begin{array}{l}\text { 30\% } \\
\text { D.P.T }\end{array}$ \\
\hline Clover hay & 30.00 & 25.00 & 20.00 & 15.00 & 10.00 & 00.00 \\
\hline Dried Potato Tops ${ }^{1}$ & 00.00 & 5.00 & 10.00 & 15.00 & 20.00 & 30.00 \\
\hline Yellow maize & 32.00 & 31.07 & 30.14 & 29.34 & 27.74 & 25.87 \\
\hline Wheat bran & 26.80 & 26.80 & 26.80 & 26.80 & 26.80 & 26.80 \\
\hline Soybean meal (\%) & 7.47 & 8.40 & 9.33 & 10.13 & 11.73 & 13.60 \\
\hline Molasses & 2.13 & 2.13 & 2.13 & 2.13 & 2.13 & 2.13 \\
\hline Nacl & 0.30 & 0.30 & 0.30 & 0.30 & 0.30 & 0.30 \\
\hline Limestone & 1.00 & 1.00 & 1.00 & 1.00 & 1.00 & 1.00 \\
\hline Premix $^{2}$ & 0.15 & 0.15 & 0.15 & 0.15 & 0.15 & 0.15 \\
\hline Dl. methionine & 0.15 & 0.15 & 0.15 & 0.15 & 0.15 & 0.15 \\
\hline Total & 100.00 & 100.00 & 100.00 & 100.00 & 100.00 & 100.00 \\
\hline C.P $\%$ & 15.42 & 15.59 & 15.56 & 15.40 & 15.50 & 15.62 \\
\hline C.F \% & 12.58 & 12.56 & 12.34 & 12.28 & 12.34 & 12.21 \\
\hline E.E \% & 3.81 & 3.39 & 3.34 & 3.24 & 3.38 & 3.38 \\
\hline NFE \% & 48.29 & 47.96 & 48.37 & 49.03 & 48.62 & 48.39 \\
\hline DE (Kcal.Kg) & 2790 & 2920 & 2930 & 2690 & 2790 & 2790 \\
\hline
\end{tabular}

Data collection:

Rabbits were individually weighed to the nearest gram at weekly intervals during the experimental period from the $5 \underline{\text { th }}$ to 13 th week of age. Daily weight gain was calculated at 5-13 weeks of age . The average amount of feed consumed per rabbit at certain period was obtained by the difference between the offered and remaining feed to the nearest gram. Feed conversion was calculated as feed intake (g) / weight gain (g) for a certain period. Protein utilization efficiency was calculated as weight gain (g) / crude protein consumed (g) for the certain period. Efficiency of energy 
utilization, it was calculated as digestible energy consumed (Kcal) / weight gain (g) for the certain period. Production index (PI) was calculated according to North (1981) as live weight $(\mathrm{Kg}) /$ feed conversion $\mathrm{x} 100$ for the certain period. Apparent digestibility coefficient (ADC) was calculated as follows :

Total nutrient intake - Total nutrient in faeces

$\mathrm{ADC}=\longrightarrow$ X 100.

Total nutrient intake

Digestible energy (DE) was calculated according to Cheek (1982) as follows : $\mathrm{DE}(\mathrm{Kcal})=5.28(\mathrm{DCP} \mathrm{g} / \mathrm{Kg})+9.51(\mathrm{DEE} \mathrm{g} / \mathrm{Kg})+4.2(\mathrm{DCF} \mathrm{g} / \mathrm{Kg})+4.2(\mathrm{DNFE}$ $\mathrm{g} / \mathrm{Kg})$

While the total digestible nutrient (TDN) was calculated as follows :

$\mathrm{TDN}=\% \mathrm{DCP}+\% \mathrm{DCF}+\% \mathrm{DNFE}+\%$ DEE $\times 2.25$ where :

DCP: digestible crude protein , DCF: digestible crude fiber, DNFE: digestible nitrogen free extract and DEE: digestible ether extract. Samples of feed and dried faeces were analyzed for dry matter (DM), crude protein (CP), ether extract (EE), crude fiber (CF) and ash according to the conventional methods of A.O.A.C (1980), using duplicate samples.

\section{Statistical analysis}

Data were analyzed to study the effects of using the dried potato tops hay in rabbit feeding. Data were analyzed by the analysis of variance according to Snedcor and Cochran (1982). Significant differences among means were detected by the method of Duncan (1955). The following model was used

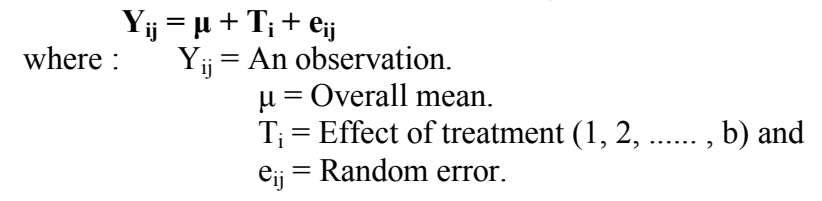

\section{RESULTS AND DISCUSSION}

Results obtained indicated that, live body weight, daily body weight gain, daily feed intake and production index of rabbits were not affected significantly by feeding different levels of dried potato tops hay in diets through the experiment from 5 to 13 weeks of age (Table 4). Rabbits fed diet contains 30\% DPT had heaviest live body weight (1313 g) at 9 weeks of age than other groups and equal weight with the control group (1918 g) at 13 weeks of age ,but rabbits fed $5,10 \% \mathrm{DPT}$ in their diets had heavier live body weight (1945 and $1947 \mathrm{~g}$ ) at 13weeks of age. Rabbits fed diets contains 5 and $30 \%$ DPT had better values of daily weight gain than the control and other groups at the whole period 5-13 weeks of age, while the group fed $15 \%$ DPT had lower value. .Rabbits fed diets contain $5,10,15$ and 20\% DPT had lower daily feed intake $(79,76,70$ and $71.2 \mathrm{~g}$ )than the control and the group fed diet contains $30 \%$ DPT ( 81 and $81.8 \mathrm{~g}$ ) at the whole period 5-13 weeks of age . Rabbits fed diets contain $5,10,15$ and $20 \%$ DPT had better values of production index than the control group by about $6.61,5.64,1.16$ and $6.61 \%$, while the group fed diet contains $30 \%$ DPT was decreased by about $2.44 \%$ at the whole period $5-13$ weeks of age .Theses results agreed with those obtained by Parigi-Bini and Chiericato (1980), Abd El-Rahim et al (1991), Zeweil (1992a), El-Kerdawy et al (1992) Ahmed et al (1994), Soliman (1995), Abd El-Lateif (1996) and El-Meligy (1996) who 
reported that feeding some agriculture by-products in the diets of rabbits did not show any negative significant effects on growth performance traits .

Feed conversion, protein utilization efficiency and efficiency of energy utilization of rabbits were affected significantly $(p<0.01)$ by feeding different levels of dried potato tops hay in diets through the experiment from 5 to 13 weeks of age (Table 4). Rabbits fed diets contain $5,10,15$ and 20\% DPT had better feed conversion(3.55, 3.53,3.51 and 3.42 )than the control and the group fed diet contains $30 \%$ DPT (3.75 and 3.78) at the whole period from 5-13 weeks of age . Rabbits fed diets contain $5,10,15$ and 20\% DPT had better values of protein utilization efficiency than the control group by about $4.65,4.65,6.39$ and $8.72 \%$, while the group fed diet contains 30\% DPT was decreased by about $2.33 \%$ at the whole period from 5-13 weeks of age . Rabbits fed diets contain $5,10,15$ and 20\% DPT had better values of efficiency of energy utilization than the control group by about 0.97 , $0.97,9.62$ and $6.74 \%$, while the group fed diet contains $30 \%$ DPT was decreased by about $0.96 \%$ at the whole period 5-13 weeks of age. Theses results agreed with those obtained by Lebas (1988), El-Gendy (1994) and Tag-El Din (1996) who reported that feeding some agriculture by-products in the diets of rabbits improved significantly feed conversion.

Table 4. Means* and standard errors $(x \pm S E)$ of live body weight, daily weight gain, feed intake, feed conversion, protein utilization efficiency, efficiency of energy utilization and production index of rabbits as affected by feeding dried potato tops hay (DPT) ${ }^{* *}$ in the diets

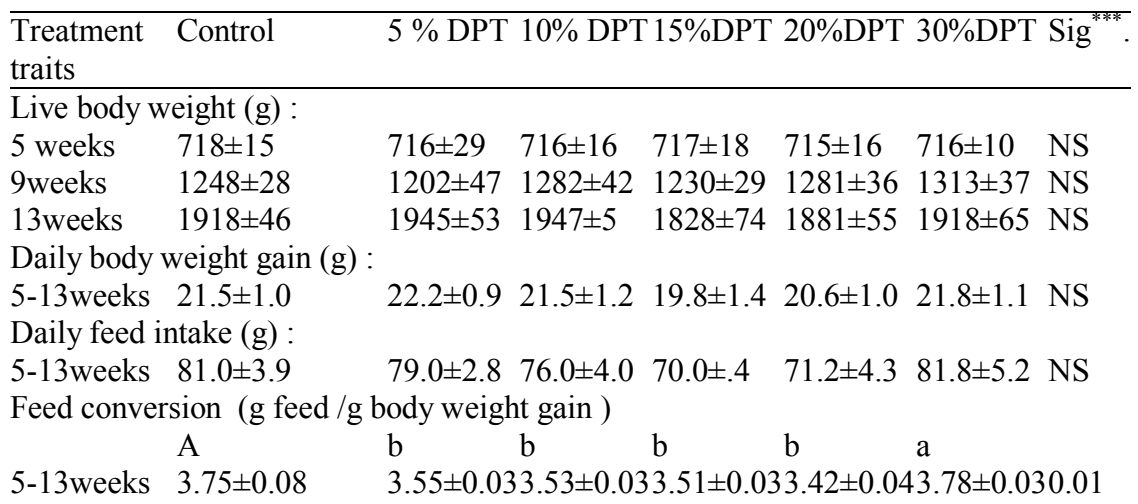

Protein utilization efficiency (weight gain $\mathrm{g} /$ protein consumed $\mathrm{g}$ ) :
$\mathrm{b}$
a
a
a $\quad \mathrm{a} \quad \mathrm{b}$

5-13weeks $1.72 \pm 0.04 \quad 1.80 \pm 0.011 .80 \pm 0.011 .83 \pm 0.021 .87 \pm 0.021 .68 \pm 0.020 .01$

Efficiency of energy utilization (DE consumed kcal /weight gain $\mathrm{g}$ ):
A
a
a
b

$\begin{array}{llllllll}5-13 w e e k s & 10.4 \pm 0.2 & 10.3 \pm 0.1 & 10 . \pm 30.1 & 9.4 \pm 0.1 & 9.7 \pm 0.1 & 10.5 \pm 0.1 & 0.01\end{array}$

Production index (live weight $\mathrm{kg} /$ feed conversion $\mathrm{X} 100$ )

$\begin{array}{llllllll}5-13 w e e k s & 51.4 \pm 1.9 & 54.8 \pm 1.9 & 54.3 \pm 2.1 & 52.0 \pm 1.9 & 54.8 \pm 1.1 & 50.2 \pm 1.8 & \text { NS }\end{array}$

* Means within each row having similar letter(s) are not significant different at ( $\mathrm{p}>0.05)$.

** DPT : dried potato tops . $\quad * * *$ Sig. : significance . 
The obtained results indicated that the differences in relative weights and preslaughter weight of all carcass traits due to the effects of feeding treatments were not statistically significant, all carcass traits slightly changed among treatments without any consistent trend in relative weights at 13 weeks of age (Table 5)

Theses results agreed with those obtained by Grandi and Angelis (1983), Lebas et al. (1988), Zeweil (1992), Mangood (1994) Ahmed et al (1994), Solaiman (1995), Abd El-Lateif (1996), El-Meligy (1996)and Tag-El-Din(1996) who reported that feeding some agriculture by-products in the diets of growing rabbits did not show any negative significant effects on carcass traits.

Table 5. Means and standard errors $(x \pm$ SE) of some carcass traits of rabbits at 13 week of age as affected by feeding dried potato tops

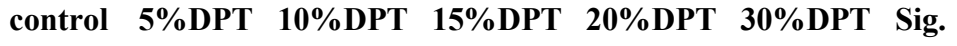

Treatment

\section{Traits}

\begin{tabular}{|c|c|c|c|c|c|c|c|}
\hline $\begin{array}{l}\text { Pre- } \\
\text { slaughter } \\
\text { wt. g }\end{array}$ & $1972 \pm 72$ & $1898 \pm 76$ & $1986 \pm 115$ & $1788 \pm 127$ & $1904 \pm 60$ & $1946 \pm 46$ & NS \\
\hline Blood w. & $\% 3.1 \pm 0.4$ & $2.9 \pm 0.3$ & $3.1 \pm 0.1$ & $3.2 \pm 0.2$ & $3.4 \pm 0.1$ & $3.0 \pm 0.3$ & NS \\
\hline Fur w. \% & $17.9 \pm 0.8$ & $17.6 \pm 0.6$ & $17.2 \pm 0.5$ & $16.0 \pm 0.4$ & $16.3 \pm 0.2$ & $16.6 \pm 0.7$ & NS \\
\hline Head w.\% & $5.3 \pm 0.1$ & $6.2 \pm 0.2$ & $5.8 \pm 0.2$ & $6.1 \pm 0.2$ & $5.7 \pm 0.1$ & $5.5 \pm 0.1$ & NS \\
\hline Liver w. \% & $3.0 \pm 0.3$ & $3.1 \pm 0.1$ & $3.1 \pm 0.1$ & $3.8 \pm 0.2$ & $3.3 \pm 0.1$ & $3.6 \pm 0.1$ & NS \\
\hline $\begin{array}{l}\text { Carcass } \\
\text { w. } \%\end{array}$ & $52.7 \pm 0.2$ & $53.0 \pm 0.3$ & $51.4 \pm 0.3$ & $52.3 \pm 0.3$ & $52.9 \pm 0.4$ & $52.7 \pm 0.2$ & NS \\
\hline $\begin{array}{l}\text { Dressed } \\
\%\end{array}$ & N. $61.1 \pm 0.2$ & $62.4 \pm 0.4$ & $60.3 \pm 0.2$ & $62.2 \pm 0.8$ & $61.9 \pm 0.4$ & $61.8 \pm 0.2$ & NS \\
\hline
\end{tabular}

The substitution of dried potato tops hay in rabbit diets instead of clover hay at any level resulted in significant differences in respect of the apparent digestibility coefficients and nutritive value (Table 6). Rabbit fed diets contain 5 and 10\% DPT recorded the best values of digestibility coefficients of DM,OM , CP,CF and NFE, while, the group fed $15 \%$ DPT had the lowest values of these coefficients, however, the group fed 30\% DPT was similar to the control group of all apparent digestibility coefficients except EE which was lower . Rabbit fed diets contain 5 and 10\% DPT recorded the best nutritive values represented as TDN \%,DCP $\%$ and DE $\mathrm{Kcal} / \mathrm{kg}$, while, the group fed 15\% DPT had the lowest coefficients values and, the group fed $30 \%$ DPT recorded nutritive values which were similar to those of the control group. 
Table 6. Means* and standard errors $(x \pm$ SE) of apparent digestibility coefficients (\%) and nutritive values as affected by feeding dried potato tops

Treatmentcontrol 5\%DPT 10\%DPT 15\%DPT 20\%DPT 30\%DPT Sig $^{* *}$

Traits

\begin{tabular}{|c|c|c|c|c|c|c|c|}
\hline \multicolumn{8}{|c|}{ A.D.coefficients } \\
\hline \multirow[t]{2}{*}{$\overline{\mathrm{DM}}$} & $\mathrm{bc}$ & $\mathrm{a}$ & $\mathrm{a}$ & $\mathrm{c}$ & $a b$ & bc & \\
\hline & $73.65 \pm 1.25$ & $77.88 \pm 0.19$ & $78.65 \pm 0.15$ & $71.68 \pm 0.10$ & $75.92 \pm 0.55$ & $74.14 \pm 0.41$ & 0.01 \\
\hline \multirow[t]{2}{*}{$\mathrm{OM}$} & & $\mathrm{a}$ & a & C & $\mathrm{ab}$ & $\mathrm{Bc}$ & \\
\hline & $74.60 \pm 1.20$ & $79.32 \pm 0.10$ & $79.62 \pm 0.30$ & $72.88 \pm 0.17$ & $776.59 \pm 0.59$ & $75.64 \pm 0.45$ & 0.01 \\
\hline \multirow[t]{2}{*}{ CP } & $\mathrm{ab}$ & $\mathrm{a}$ & $\mathrm{a}$ & $\mathrm{b}$ & $\mathrm{a}$ & $\mathrm{ab}$ & \\
\hline & $79.76 \pm 0.87$ & $81.75 \pm 0.11$ & $82.99 \pm 0.31$ & $76.62 \pm 0.24$ & $80.89 \pm 0.09$ & $79.96 \pm 0.35$ & 0.01 \\
\hline \multirow[t]{2}{*}{$\mathrm{EE}$} & $\mathrm{a}$ & $\mathrm{ab}$ & $\mathrm{b}$ & c & $\mathrm{b}$ & $\mathrm{b}$ & \\
\hline & $77.74 \pm 1.02$ & $74.81 \pm 1.00$ & $71.44 \pm 0.10$ & $63.09 \pm 0.8$ & $69.89 \pm 0.96$ & $70.44 \pm 1.70$ & 0.01 \\
\hline \multirow[t]{2}{*}{$\mathrm{CF}$} & & $\mathrm{a}$ & $\mathrm{a}$ & c & $\mathrm{ab}$ & & \\
\hline & $42.1 \pm 2.3$ & $50.2 \pm 0.1$ & $52.1 \pm 0.1$ & $36.4 \pm 0.7$ & $49.3 \pm 1.3$ & $42.3 \pm 0.6$ & 0.01 \\
\hline \multirow[t]{2}{*}{ NFE } & $\mathrm{b}$ & a & $\mathrm{a}$ & $\mathrm{b}$ & $\mathrm{ab}$ & $\mathrm{ab}$ & \\
\hline & $81.18 \pm 1.07$ & $86.25 \pm 0.19$ & $86.10 \pm 0.63$ & $81.45 \pm 0.01$ & $82.71 \pm 0.53$ & $83.06 \pm 0.37$ & 0.05 \\
\hline
\end{tabular}

Nutritive value

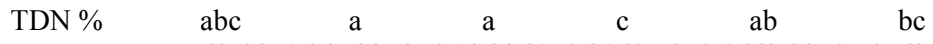

$\begin{array}{lllll} & 63.44 \pm 1.04 & 66.53 \pm 0.1266 .41 \pm 0.2160 .79 \pm 0.1663 .98 \pm 0.50 & 63.09 \pm 0.43 & 0.01\end{array}$

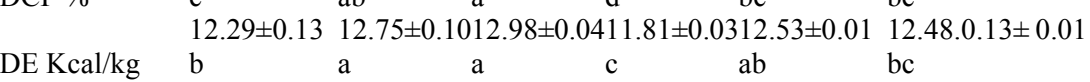

$2798.5 \pm 45.32913 .9 \pm 5.12931 .0 \pm 8.62681 .9 \pm 7.82823 .9 \pm 19.02786 .5 \pm 22.20 .01$

* Means within each row having similar letter(s) are not significant different at ( $\mathrm{p}>0.05)$.

**Sig. : significance.

\section{CONCLUSION}

The obtained results from this experiment indicate that potato tops hay can be used instead of clover hay up to $30 \%$ of the diet without any detrimental effect.

\section{REFERENCES}

Abd El-Lateif, A. E. A., 1996. Effect of treated low quality roughages on rabbits. M. Sc. Thesis, Fac. of Agric., Menoifiya University.

Abd El-Rahim, M. I., Soad S. Ahmed, Fatma. R. Abdallah, M. A. El-Fieshawy, 1991. Effect of feeding cassava on growth performance, carcass quality, blood constituents and organs histology of growing rabbits. Egypt J. Rabbit Sci., 1: 61.

Abd El-Razik, W. ,1996. Effect of substitution of tomato pomace for corn in growing rabbit diets on growth performance and carcass traits. Egypt. J. Rabbit Sci., 6: 7986.

Abd El-Samee, A. M., K. M. El-Gendy and H. Ibrahim ,1992. Growth performance and some related physiological changes in rabbit as affected by feeding under sub tropical conditions. Egypt. J. Rabbit Sci., 2: 25-36.

Abdel-Samee, A. M., K. M. El-Gendy and H. Ibrahim ,1994. Rabbit growth and reproductive performance as influenced by feeding desert forage (Acacia soligino) and (Atriplex nummlaria) at north Sinai. Egypt. J. Rabbit Sci., 4: 25-36.

Ahmed, S. S., K. M. El-Gendy, Ibrahim, A. A. Rashwan and M. I. Tawfeek „1994. Growth performance, digestibility, carcass traits and some physiological aspects 
of growing rabbit fed tomato pomace as a substitution for alfalfa meal. Egypt. J. Rabbit Sci., 4:1-13.

A.O.A.C. ,1980. Association of official analytical chemist. Official Methods of Analysis. $13^{\text {th }}$ ED., Washington, D.C.

Cheeke, P. R.,1977. Advances in rabbit nutrition reserach. Feedstuffs, 18 April, 2043.

Cheeke, P. R. ,1982. Rabbit Feeding and Nutrition. Academic Pres., Orlando, FL. Duncan, D. B. , 1955. Multiple range and multiple F tests. Biometrics, 11: 1-42.

Eleraky, W. A. and W. E. Mohamed ,1996. Growth performance, carcass traitsand some related physiological changes of growing rabbit, fed on acacia and water hyacinth. Egypt J. Rabbit Sci., 6: 87-98.

El-Gendy, K. M. ,1994. Cassava as a new animal feed in Egypt. 6- Complete pelleted diets containing cassava products for growing NZW rabbits. Egypt. J. Rabbit Sci., 4:133-147.

El-Kerdawy, D. M. A., A. A. Rashwan, H. Ibrahim and K. M. El-Gendy ,1992. Digestibility, growth performance, carcass traits and some physiological aspects of growing New Zealand white rabbits as affected by partial substitution of concentrates with carrot-tops hay and feeding time. Egypt. J. Rabbit Sci., 2:61-71.

El-Meligy M.,1996. Studies on the effects of some non conventional feeding sources on poultry productivity. "Effects of using turnips in rabbit feeding". M.Sc. Thesis, Fac. of Agric., Mansoura University.

El-Sayaad. G. A. E., M. R. El-Mahdy and A. S. Soliman ,1995. Artichoke bracts as a food processing waste product in growing rabbit diets. Egypt J. Rabbit Sci., 5: 125-134.

Lebas, F. ,1988. First attempt to study Chick-peas utilization in growing rabbits feeding. $4^{\text {th }}$ World Rabbit Congress, Bodapest, Hungary.

North, O.M., 1981. Commercial Chicken Production Manual. 2 $\frac{\text { nd }}{\text { Ed., AVI }}$ Publishing Company, Inc., Westpor, Connecticut.

NRC, 1977. National Research Council, Nutrient Requirement of Domestic Animals. Nutrition Requirement of Rabbits. Washington, D.C., USA.

Parigi-Bini, R. and G. Chiericato ,1980. Utilization of grape marce by growing rabbits. 11 World rabbit Congress. (1980). Spain.

Snedecor, G. W. and G. W. Cochran (1982). Statistical Methods. Iowa State University Press., $6^{\text {th }}$ Edition, Ames, USA.

Soliman, A.S., 1995 Studies on growth performance and meat yield in poultry. Effect of using sweet potato in feeds of meat rabbits. M. Sc. Thesis, Fac. Agric., Mansoura University.

Spedding, C. R. W. ,1979. Vegetable Productivity “ The Role of Vegetable Feeding People and Livestock". MacMillan Publishing Ltd., London and Basing Stock.

Tag-El-Din, T.H., 1996. Productive performance of meet rabbits as affected by partial replacement of clover hay by okra and sugar beet processing by-products. J. Agric. Sci., Mansoura Univ., 21: 4339-4350.

Walsingham, J. M. ,1972. Ecological efficiency studies. 1-Meat production from rabbits. Grassland Reserach Institute Report, No. 12.

Zeweil, H. S. ,1992. Artichoke (Cynara scolymus) canning by-products as rabbit feed. Egypt. Poult. Sci., 12: 1-16. 


\title{
تأثير إستخدام دريس عرش البطاطس فى علائق الأرانب الناميسة على الأداء الإنتاجي ومعاملات الهضم وصفات اللحم.
}

\author{
تاج الدين حسن تاج الدين'، أمينه عبد المطلب السروى' ، عوض لطفى عوض
}

\section{1- قسم إنتاج الدواجن، كلية الزراعة، جامعة المنصوره، ؟ - معهل بحوث الإتتاج الحيواني، الدقي}

أجريت هذه الدراسة في مزرعة الأرانب التابعة لمشروع تحسين إنتاجية الأرانب باستخدام علائق غير

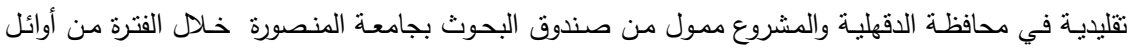

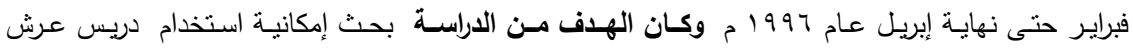

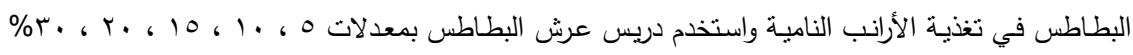

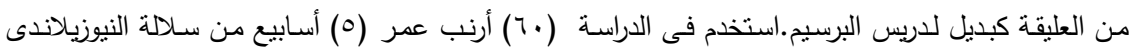

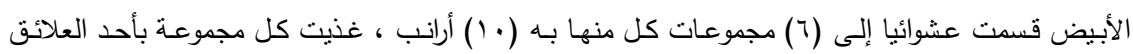

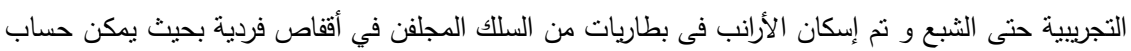

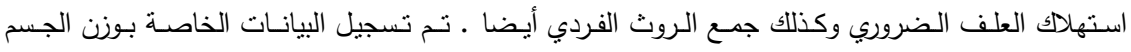

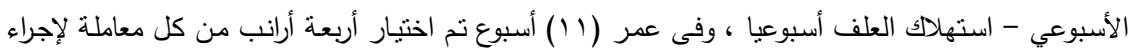

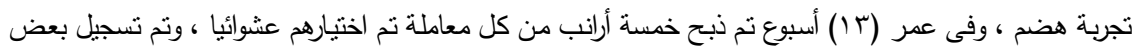
بيانات الذيحة والفضلات.وكاتت النتائج المتحصل عليها كما يلي :كان وزن الجسم الحي في الأرانب المغذاة

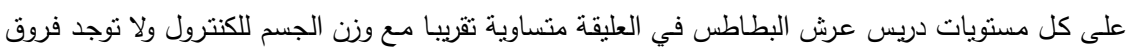

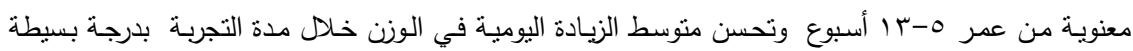

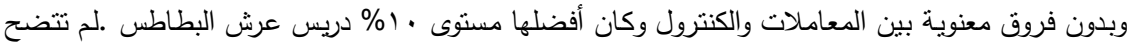

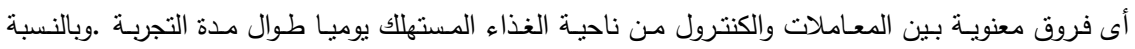

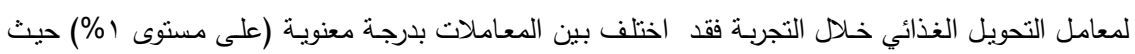

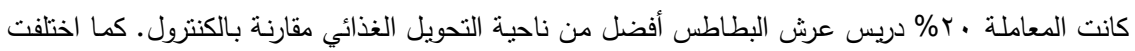

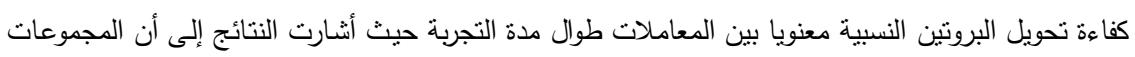

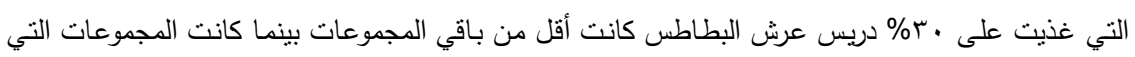

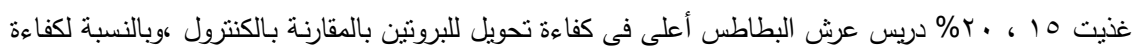

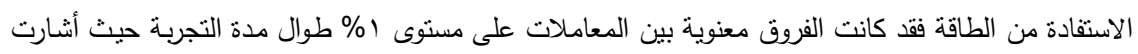

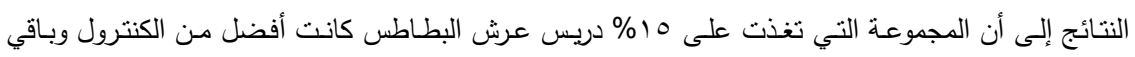

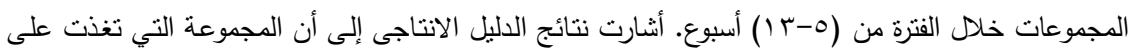

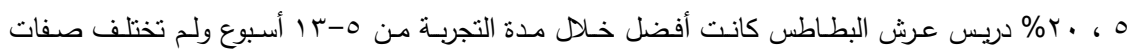

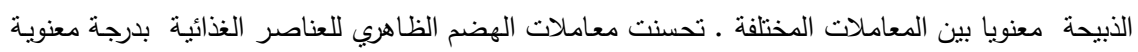


فيما عدا المستخلص الإثرى للأرانب التي غذيت على ه ، . 1\% دريس عرش البطاطس في العليقة كذلك

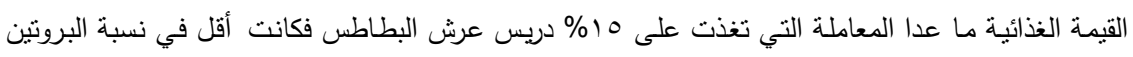

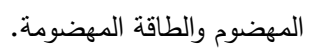

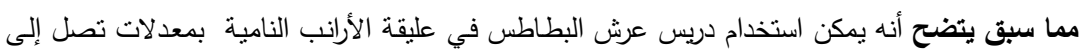

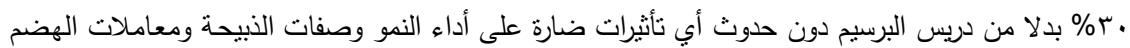

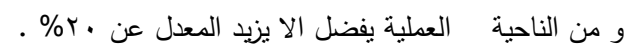

